\title{
COMBINING ABILITY OF INBRED LINES DERIVED FROM A YELLOW FLINT MAIZE SYNTHETIC CMS 53
}

\author{
ELTO EUGENIO GOMES E GAMA ${ }^{1}$, WALTER FERNANDES MEIRELES ${ }^{1}$, PAULO EVARISTO \\ GUIMARÃES ${ }^{1}$, ROMÁRIO GAVA FERRÃO ${ }^{2}$, SIDNEY NETO PARENTONI ${ }^{1}$, CLESO ANTÔNIO \\ PATTO PACHECO ${ }^{1}$, MANOEL XAVIER DOS SANTOS ${ }^{1}$, ANTÔNIO CARLOS DE OLIVEIRA ${ }^{1}$
}

\author{
${ }^{1}$ Pesquisadores, Embrapa Milho e Sorgo. Caixa postal 151, CEP. 35701-970 Sete Lagoas, MG. E- mail: \\ gamaelto@cnpms.embrapa.br (autor para correspondência). \\ ${ }_{2}^{2}$ Pesquisador, Imcaper. Caixa postal 151, CEP. 39900-000 Linhares, ES.
}

Revista Brasileira de Milho e Sorgo, v.2, n.3, p.97-102, 2003

\begin{abstract}
The objectives were to study the combining ability of lines, derived from synthetic maize (Zea mays L.) CMS 53, in a diallel crosses, to identify lines for developing more stable and superior yielding hybrids combinations with a dent heterotic group. The 9 inbreds were crossed to form 36 single crosses, in 1999. Parental inbreds and crosses together with a single cross commercial hybrid were evaluated using a randomized complete block design with 2 replications in four locations during the 1999/00 summer season. Data were collected for several agronomic traits, but only ear yield $\left(\mathrm{kg} \mathrm{ha}^{-1}\right)$ is discussed. For the analysis of this trait, Griffing's (1956) method 2, was used. The combining ability showed highly significant $(\mathrm{P}<0.01)$ effects for locations, crosses, lines, general combining ability (GCA), and specific combining ability (SCA). Genotype $\mathrm{x}$ Locations was highly significant, but SCA x Location was $(\mathrm{P}<0.05)$ significant. Means of the crosses over locations ranged from $6678 \mathrm{~kg} \mathrm{ha}^{-1}$ to $11122 \mathrm{~kg} \mathrm{ha}^{-1}$. Results showed that additive and non-additive gene effects were important in this diallel study. There were specific superior crosses for each location indicating the importance of SCA effects over GCA effects at all locations. The selected lines should be useful to a breeding program in tropical conditions.
\end{abstract}

Key words: Zea mays L., diallel, inbred lines, combining ability, ear yield.

\section{CAPACIDADE DE COMBINAÇÃO DE LINHAGENS DERIVADAS DO SINTÉTICO DURO DE MILHO CMS 53}

RESUMO - Os objetivos deste trabalho foram estudar a capacidade de combinação e a identificação de linhagens promissoras derivadas de um sintético de milho (Zea mays L.) CMS 53, de grãos duros, em cruzamentos dialelo, como indicação para a formação de híbridos com maior estabilidade e maior potencial de produção quando em cruzamento com linhagens de um outro grupo heterótico dentado. Foram produzidos 36 híbridos simples dos cruzamentos entre nove linhagens-elites, em 1999. As linhagens parentais mais os híbridos simples e um híbrido simples comercial usado como testador foram avaliados usando-se blocos casualizados com duas repetições, em quato locais, no ano agrícola de 1999/2000. Foram coletados dados para várias características de planta e espigas, mas foram usados somente os dados de produção de espigas $\left(\mathrm{kg} \mathrm{ha}^{-1}\right)$ dos quatro locais, e que foram analisados utilizandose o método 2, modelo 1 de Griffing (1956). Os resultados da análise da variância combinada mostraram efeitos altamente significativos $(\mathrm{P}<0.01)$ para locais, cruzamentos, linhagens, $C G C$ e CEC. A interação genótipos e locais foi altamente significativa; entretanto, a CEC e locais foi 
significativa a $\mathrm{P}<0.05$. As médias dos cruzamentos nos quatro locais variaram de $6.678 \mathrm{~kg} \mathrm{ha}^{-1}$ to $11.122 \mathrm{~kg} \mathrm{ha}^{-1}$. Os resultados mostraram que, tanto os efeitos aditivos como os não aditivos, foram importantes neste estudo. Foram identificados alguns cruzamentos específicos para cada local, indicando a importância superior da CEC sobre a CGC em todos locais de teste. As linhagens selecionadas podem ser de grande valia para programas de melhoramento nas condições tropicais.

Palavras chave: Zea mays L., dialelo, linhagem, capacidade de combinação, produção de espigas.

Maize inbred lines derived from different germplasm can exhibit varying response patterns when grown in different environments. Heterosis has been used in maize breeding programs since Shull (1909) described the concept of single cross hybrids. The yield of hybrids depends on the combining ability of the lines involved in their development. Therefore, breeders are interested in identifying lines that perform well in crosses.

The diallel cross methodology gives the opportunity to calculate GCA and SCA (Sprague \& Tatum, 1942). The diallel crosses among lines have been utilized by plant breeders to better understand the nature of gene action controlling traits of agricultural importance and evolution (Kempthorne \& Curnow, 1961), and to compare the relative magnitudes of the general combining ability of a group of lines (Hayes \& Johnson, 1939).

Diallel analysis is applicable at an advanced breeding stage when a selected number of lines is to be tested (Yordanov, 1983). The limitation of this analysis is that a large number of crosses are required to test a small set of lines (Gonçalves, 1987; Hallauer \& Miranda Filho, 1988; Martins \& Miranda Filho, 1997).

Sprague \& Tatum (1942) reported that GCA was relatively more important than SCA for unselected inbred lines, but the opposite was observed for selected lines. Inheritance studies have shown that grain yield is a quantitative trait under grater influence of SCA effects than GCA, indicating the greater importance of non-additive gene action in controlling grain yield.

The majority of the research or measurements of GCA and SCA effects, has been with temperate inbred lines rather than tropical lines. Additional studies are needed to examine similar parameters with lines derived from tropical synthetic germplasm.

Information on inbred lines derived from a population is important in a breeding program. Lines with high GCA can be used to test self-progenies from a contrasting heterotic group to produce single cross hybrids. And single crosses can be used in the final double cross hybrids.

The objectives of this study were to use diallel crosses to evaluate the combining ability effects of nine lines selected from the tropical flint type synthetic CMS 53.

\section{Material and Methods}

Two hundred $\mathrm{S}_{2}$ maize progenies, from a synthetic population (CMS 53) with flint kernel, developed by the National Center for Maize and Sorghum Research (EMBRAPA), were top-crossed with a contrasting heterotic dent type synthetic (CMS $61)$ and the hybrids were evaluated for yield and other characteristics, at five locations in the states of MG, PR, GO and SP, in 1997/98. Ten lines involved in the best crosses were selfed until $\mathrm{S}_{6}$ and their seeds were increased.

Nine selected lines with high yield potential and good agronomic characteristics were chosen for 
this study. These lines, with inbreeding coefficient $(\mathrm{F})$ near one, were crossed in a $9 \times 9$ diallel scheme.

The 36 single crosses, the 9 inbred lines parents, and a commercial single-cross hybrid as a check (C 901) were evaluated using a randomized complete block design with two replications. The experiments were evaluated at four locations, at Sete Lagoas (MG), Janaúba (MG), Goiania (GO), and Londrina (PR), during the 1999/2000 summer season. Each plot consisted of two $4 \mathrm{~m}$ rows, spaced at $0,90 \mathrm{~m} \times 0,20 \mathrm{~m}$ between and within rows, respectively. Data were collected for several traits, but only ear yield is presented in this study.

The analyses of variance were performed using an adaptation of Griffing's Method 2, Model I, diallel analyses (Griffing, 1956).

\section{Results and Discussion}

The mean ear yield of the single crosses over the four locations (Table 1) ranged from $11122 \mathrm{~kg}$ $\mathrm{ha}^{-1}$ (L $5 \times \mathrm{L} 7$ ) to $6678 \mathrm{~kg} \mathrm{ha}^{-1}$ (L $2 \times \mathrm{L} 8$ ). The hybrid check out yielded the best single cross by $11,31 \%$. The lower yielding inbred line (L8) produced $889 \mathrm{~kg} \mathrm{ha}^{-1}$, and the higher yielding line (L3) $3511 \mathrm{~kg} \mathrm{ha}^{-1}$. The individual analysis of variance (data not shown) showed highly significant differences among genotypes $(\mathrm{P}<0,01)$ at all locations.
For yield over locations, the CV of $13,15 \%$ was considered of acceptable magnitude (Scapim et al.,1995).

Highly significant $(\mathrm{P}<0,01)$ differences for locations, genotypes (single-crosses and inbred lines) and genotype $\mathrm{x}$ locations were detected in the combined analysis of variance, (Table 2). Inbred lines and single crosses also showed highly significant differences $(\mathrm{P}<0,01)$. The single crosses yielded differently at tested locations, indicating genetic differences and behavior among them even though the inbreds were derived from a same heterotic population. These results agrees with Sprague \& Eberhart (1977) and Gama et al. (1995), who found that single crosses with a narrow genetic base have a greater environmental interaction than germplasms from a broad genetic base.

Joint analysis of variance of diallel data across environments for GCA and SCA effects showed highly significant differences $(\mathrm{P}<0.01)$ for locations, GCA, SCA and SCA x locations, but GCA $x$ environments interaction was $(P<0.05)$ significant (Table 3).

There are instances in the literature where the relative sizes of mean squares have been used to

TABLE 1. Mean yield $\left(\mathrm{kg} \mathrm{ha}^{-1}\right)$ for the 9 lines (diagonal) derived from the synthetic CMS 53 and the 36 single-crosses (above diagonal), and the commercial hybrid, evaluated over four locations.

\begin{tabular}{cccccccccc}
\hline Parents & $\mathbf{1}$ & $\mathbf{2}$ & $\mathbf{3}$ & $\mathbf{4}$ & $\mathbf{5}$ & $\mathbf{6}$ & $\mathbf{7}$ & $\mathbf{8}$ & $\mathbf{9}$ \\
\hline 1 & 3400 & 9777 & 9366 & 9277 & 9066 & 8922 & 10911 & 8255 & 8544 \\
2 & & 2288 & 8011 & 9522 & 9477 & 9466 & 9488 & 6677 & 9866 \\
3 & & & 3511 & 8566 & 8988 & 7900 & 10422 & 9888 & 6922 \\
4 & & & & 2233 & 8133 & 8988 & 10722 & 7455 & 8600 \\
5 & & & & & 2377 & 6833 & 11122 & 9277 & 8011 \\
6 & & & & & & 2966 & 9466 & 9733 & 8522 \\
7 & & & & & & & 2777 & 9777 & 10122 \\
8 & & & & & & & & 888 & 10856 \\
9 & & & & & & & & & 1355 \\
\hline
\end{tabular}

Single cross hybrid-check: $12541 \mathrm{~kg} \mathrm{ha}^{-1}$. 
TABLE 2. Mean squares for the combined analysis of variance for yield $\left(\mathrm{kg} \mathrm{ha}^{-1}\right)$ of 36 crosses and 9 parents from the synthetic CMS 53.

\begin{tabular}{lcc}
\hline Source of Variation & d.f. & Mean Square \\
\hline Location (L) & 3 & $193,851,028^{* *}$ \\
Genotype (G) & 44 & $35,393,554^{* *}$ \\
Crosses & 35 & $40,641,378^{* *}$ \\
Lines & 8 & $14.982,417^{* *}$ \\
Groups(Lines vs Crosses) & 1 & $15,008,794^{* *}$ \\
G x L & 132 & $1,797,791^{* *}$ \\
Combined Error & 144 & $1,303,468$ \\
\hline Mean $=7424$ & $\mathrm{CV} \%=13$ & \\
\hline
\end{tabular}

** = Significant at 0.01 level of probability.

TABLE 3. Combined diallel analysis of variance for yield $\left(\mathrm{kg} \mathrm{ha}^{-1}\right)$ of the 9 lines and 36 crosses derived from synthetic CMS 53.

\begin{tabular}{lcc}
\hline Source of Variation & d.f. & Mean Square \\
\hline Locations (L) & 3 & $193,851,028^{* *}$ \\
GCA & 8 & $5,874,225^{* *}$ \\
SCA & 36 & $41,953,405^{* *}$ \\
GCA x L & 24 & $1,664,752^{*}$ \\
SCA x L & 108 & $1,827,355^{* *}$ \\
Combined Error & 144 & $1,303,468$ \\
\hline
\end{tabular}

$*, * *=$ Significant at 0,05 and 0,01 levels of probability, respectively.

assess the relative importance of general and specific combining ability. Baker (1978) suggested an expression of the ration between GCA and SCA component of variance, to infer about the relative importance of general and specific combining abilities in determine progenies performance. The closer the ratios to unity, the greater the predictability based on general combining ability alone. In this study, the variation among the SCA effects had greater contribution to the total variation for ear yield than GCA effects indicating significant non-additive effects (Table 3). According to Hallauer \& Miranda Filho (1988), dominance effects for grain yield are more relevant than for other maize traits. Different results were found by Paterniani et al. (2000), using a set of selected lines from CIMMYT, indicating greater importance of additive effects than non-additive effects.

Lines L7 and L9 had the highest positive and negative GCA effects, respectively (Table 4). Four out of nine lines presented positive GCA effects. Similar results were obtained by Nass et al. (2000). The highest positive and negative SCA effects were found for the crosses L2 x L6 and L4 x L3, respectively. Vasal et al (1992) and Gama et al. (1995), reported that single crosses produced by crossing lines from different source populations had more positive SCA effects than those involving crossing lines from the same population.

The results of this study show that the lines likely to be useful in crosses in a breeding program are L7, L1 and L6, since they present high positive 
TABLE 4. Estimates of GCA (diagonal), SCA effects ( $\mathrm{kg} \mathrm{ha}^{-1}$ )(above diagonal), of the 9 lines and 36 crosses from synthetic CMS 53, over the four locations.

\begin{tabular}{cccccccccc}
\hline Parent & $\mathbf{1}$ & $\mathbf{2}$ & $\mathbf{3}$ & $\mathbf{4}$ & $\mathbf{5}$ & $\mathbf{6}$ & $\mathbf{7}$ & $\mathbf{8}$ & $\mathbf{9}$ \\
\hline 1 & 71 & 1221 & 1014 & 1051 & 1333 & 508 & 1457 & -64 & 483 \\
2 & & -9 & 219 & 1395 & 665 & 2133 & 862 & 417 & 1856 \\
3 & & & -253 & -250 & 1090 & 475 & 1962 & 1662 & 930 \\
4 & & & & 7 & 871 & 1457 & 1385 & 996 & 1462 \\
5 & & & & & -109 & 7 & 1383 & 1646 & 472 \\
6 & & & & & & 43 & 733 & 1327 & -15 \\
7 & & & & & & & 608 & 1205 & 662 \\
8 & & & & & & & & -84 & 1419 \\
9 & & & & & & & & & -274 \\
\hline
\end{tabular}

$\begin{array}{llllllll}S E & \hat{g}_{i} & \hat{g}_{j} & 237 & \text { SE } & \hat{S}_{i} & \hat{S}_{j} & 793\end{array}$

GCA for yield. Those lines can also be used as testers for lines derived from CMS 61 for single-cross productions. Some high yielding single crosses, e.g. $\mathrm{L} 2 \times \mathrm{L} 6$ and $\mathrm{L} 3 \times \mathrm{L} \mathrm{7}$, can be considered for hybrid productions.

\section{Conclusions}

Some of the single crosses presented good yields compared to the check hybrid over the four locations, indicating the good potential of the selected lines for hybrid development.

The line $\mathrm{L} 7 \mathrm{had}$ the highest GCA effect, while lines L9 had lowest GCA effects for ear yield.

SCA mean square value was greater than GCA mean square, indicating the importance of nonadditive effects for this set of lines.

The mean yield of the check was greater than the means of the single crosses produced with lines extracted from the same synthetic population, CMS 53.

\section{References}

BAKER, R. J. Issues on diallel analysis. Crop Science, Madison, v. 18, p 533 - 536, 1978.

GAMA, E. E. G., HALLAUER, A. R.; FERRÃO, R. G., et al. Heterosis in maize single crosses derived from a yellow Tuxpeño variety in Brazil. Revista Brasileira de Genética, Ribeirão Preto, v. 18, p. $81-85,1995$.

GONÇALVES, P. S. Esquema circulante de cruzamentos para avaliação de linhagens de milho (Zea mays L.) ao nível interpopulacional. 1987. $140 \mathrm{f}$. Tese (Doutorado em em Genética e Melhoramento), Escola Superior de Agricultura "Luiz de Queiroz”, Universidade de São Paulo, Piracicaba.

GRIFFING, B. Concept of general and specific combining ability in relation to the diallel crossing systems. Australian Journal of Biological Science. v. 9, p. 463 - 493, 1956.

HALLAUER, A. R.; MIRANDA FILHO, J. B. Quantitative genetics in maize breeding. Ames: Iowa State University Press, 1988.

HAYES, H.K., JOHNSON, I.J. The breeding of selfed lines of corn. Journal of America Society of Agronomy, Madison, v. 31, p. 710 - 724, 1939.

KEMPTHORNE, O., CURNOW, R. N. The partial diallel cross. Biometrics, Washington, v. 17, p. 229 - 50, 1961. 
MARTINS, C. S.; MIRANDA FILHO, J. B. Evaluation of inbred lines from two maize (Zea mays L.) brachytic populations in single crosses following the two factor mating design. Brazilian Journal of Genetics, Ribeirão Preto, v. 20, n. 2, p. 265 - 273, 1997.

NASS, L. L.; LIMA, M.; VENCOVSKY, R. et al. Combining ability of maize inbred lines evaluated in three environments in Brazil. Scientia Agrícola, Piracicaba, v. 57, n. 1, p. 129 - 134. jan./mar.2000.

PATERNIANI, M. E. A. G. Z.; SAWAZAKI, E.; DUDIENAS, C. et al. Diallel crosses among maize lines with emphasis on resistance to foliar diseases. Genetics and Molecular Biology, Ribeirão Preto, v. 23 , n. 2 , p. $381-385,2000$.

SCAPIM, C. A.; CARVALHO, C. G. P.; CRUZ, C. D. Uma proposta de classificação dos coeficientes de variação para a cultura do milho. Pesquisa Agropescuária Brasileira, Brasília, v. 30, p. 683 - 686, 1995.
SHULL, G.F. A pure line method of corn breeding. Report of the American Breeders Association, v. 5, p. $51-59,1909$.

SPRAGUE, G. F.; TATUM, L. F. General vs. Specific combining ability in single cross of corn. Journal of the American Society of Agronomy, Madison, v. 34, p. 923 - 932, 1942.

SPRAGUE, G. F.; EBERHART, S. A. Corn breeding. In: Sprague, G.F. (Ed.) Corn and corn improvement. 2.ed. Madison: American Society of Agronomy, 1977.p. 305 - 306.

VASAL, S. K.; SRINIVASAN, G.; HAN, G. C.; GONZALES, C. F. Heterotic patterns of eightyeight white subtropical CIMMYT maize lines. Maydica, Bergamo, v. 37, p. 319 - 327, 1992.

YORDANOV, M. Heterosis in the tomato. In: FRANKEL, R. (Ed.) Heterosis. New York: Springer-Verlag, 1983.p. 139 - 219. 